\title{
EQUITY IN PUBLIC HEALTH POLICIES. THE PERSPECTIVE OF DIABETIC PATIENTS
}

\section{Antonio Sandu', Magda lonela Crițan', Simona Irina Damian ${ }^{3}$}

\author{
'Stefan cel Mare University of Suceava, Romania, \\ e-mail:antonio1907@yahoo.com \\ ${ }^{2}$ Stefan cel Mare University of Suceava, Romania, \\ 3 "Gr. T. Popa" University of Medicine and Pharmacy from laşi, Romania; \\ Forensics Institute of Iasi, Romania; e-mail:si_damian@yahoo.com .
}

\begin{abstract}
Health policies are correlated with the development of the society both nationally and locally. On the other hand, the allocation of resources for health services is a priority in regions with a lower degree of local development, where the health of the population is higher because of the more difficult access to health services, the lack of information and the postponement of the decision because of the lack of personal health care resources. Under these circumstances, investment in repairers' health policies becomes absolutely necessary in order to ensure a minimum equity of healthcare systems in that state.
\end{abstract}

KE Y W ORDS - Health Programs; National Diabetes Program; Chronic Care Self-Care Management.

\section{INTRODUCTION}

Depending on the socio-cultural significance given to suffering by the society, the reaction of individuals to disease and pain also varies, but also to other disconcerting physiological states, all of which have a socio-cultural determination as a result of a social construction process. The present article aims to analyse patient discourses on the national health program in the field of diabetes.

\section{LITERATURE REVIEW}

The evaluation of national health programs (Moisa, Pârvu, \& Ioan, 2019) allows decision makers to review health policies in the areas mentioned in accordance with the specifics of Romanian patients (adolescents). In Romania this is a priority due to the dynamics of the health system in the last two decades: Romania (CEU, 2011) has since 2006 a national diabetes program (FENDT \& IDF Europe, 2008) (whose technical coordination belongs to the National Institute for Diabetes, Nutrition and Metabolic Diseases), coordinates the annual monitoring and prevention of diabetes complications, self-monitoring, access to specific treatments, including insulin pumps and the

\section{Article history:}

Received 28 February 2019

Received in revised form 26 March 2019

Accepted 26 March 2019 administration of the National Diabetes Registry, underway.

The components of the National Diabetes Program are prevention and control (Epping-Jordan, Pruitt, Bengoa, \& Wagner, 2004; Everson, Maty, Lynch, and Kaplan, 2002). The responsibility (Britt, Moore, Adler, \& Bartone, 1995) for patient care (Kamberi, 2018; Singh \& Ham, 2006) in the case of patients with diabetes (Capplen \& Norheim, 2005) non-insulin dependent patients and diabetics, according to the National Program for Diabetes, is of the general physicians, for non-insulin-dependent patients, and of the diabetologists for the insulin-dependent patients. A three-month check-up at the specialist doctor is required for every diabetic patient enrolled in the county centers. In the framework of the National Diabetes Program, we aim to investigate the actual practices in the medical system and how they influence the construction of the autonomy of individuals (CNAS, n.d.).

In the framework of prevention, the national diabetes program ensures the monitoring of persons aged over 45 or of groups at risk of illness, every three years (Order No. 1332/2018). Diabetes is considered a costly disease due to the chronic nature, the severity of the complications and the means necessary to control evolution, and poverty, illiteracy, low level of health education (Galan, 2017, Manolachi \& Visitei, 2018), especially in rural areas, increase the risk of death by the complications of diabetes.

\section{METHODOLOGICAL DESIGN}

This research is a secondary data analysis applied to focus groups and interviews with diabetic patients conducted during the 2011-2013 period in the N.-E. region of Romania, which was dedicated to the Lifestyle and Health Behaviour of People with Chronic Diseases. Focus groups and interviews were attended by 6 or 4 people, of which 8 female and 2 male, diagnosed with type 1 insulin dependent diabetes, aged between 18 and 42 years.

Research objective

The purpose of this micro-research is to understand how patients with chronic diseases - diabetes 
mellitus - relate to public health policies and programs related to their illnesses.

Interpretation of data

The data interpretation was carried out in the form of content analysis, with a series of issues related to national health programs, mainly the national diabetes program, as well as aspects related to the ethical dimensions of the health program.

Discussions

Research boundaries are given by the relative age of the data collected during the 2011-2013 period. Another limit is the ratio between the number of female and male respondents in research, and the relatively small number of participants in the research. However, we believe that the data, although not a complete evaluation of the Diabetes Program, may constitute a set of benchmarks for patients' perception of the ethical dimension of this program, findings that may be useful in developing health policies and programs at the global level. We highlight the descriptive character of the analysis contained in the article, which is placed at the level of a medium-level theory of generality, without seeking to construct a complete theory with general explanatory power, but only to sketch, in an exploratory manner, a series of significant directions in the shaping of health policies in the field.

\section{RESULTS}

Chronic condition

The chronic patient experiences the chronic condition, as the normality of his life, as what defines him, or will define all his life.

You realize that a lady appeared in front of me who told me that I was to make the first injection at 1 o'clock and that I would spend all my life doing four injections a day, that I would live a normal life. It was ... How to live a normal life with 4 injections, but I got used to somehow. (FG2).

When lifestyle is essential for a proper management of self-care, accurate and timely information can be vital, constituting the difference between maintaining an approximately normal health condition within the limits of chronic patient-specific normality, and irreversible disintegration of the health condition.

I extend my life a little, I told you my girlfriends, the salon colleagues, do not live anymore. I extended my life, having the chance that my parents would have a higher education and would teach me. Since they were from the country side, they probably did not have this chance, to understand that they had to eat on time, to ... (FG2).
Right to health care

The right to health care, although a universal right in itself, depends on the level of development of the society in which the patient lives, being essentially about the fact that the limits of the possibility of a management of self-care is correlated with the inequities existing in that society.

I could tell you that in my time, the injections were made of glass with a metal needle, and I had to boil them every time. Because I was a kid and it was really hard for me to work with those ones, and because it was hard for me to always look for a stove to boil them, I would have skipped them. That was when there was insulin, when there was no insulin, I did not do them at all. That's where a lot of complications have arisen... I'd sue the Romanian State if I would get some damages, and with the money I get I buy my blood sugar tests so I can be alive for a few more years ( $F G 2$ ).

The quality of medication, as well as the limits within which the access to health resources is publicly ensured, are related to the level of development of the society and the health policies developed at the level of each state, even if this in practice means diminishing the chronic life expectancy of the patient.

(..) in other European countries they receive ... there are 4 testsper day free of charge, only one for us. Although we should do one before each meal or every insulin. If you want to live longer (FG2).

Health policies and level of societal development

Health policies are correlated with the development of the society both nationally and locally. On the other hand, the allocation of resources for health services is a priority in regions with a lower degree of local development, where the health of the population is higher because of the more difficult access to health services, the lack of information and the postponement of the therapeutic decision because of the lack of personal health care resources. Under these circumstances, investment in repairers' health policies becomes absolutely necessary in order to ensure a minimum equity of healthcare systems in that state.

There was no phone to call the ambulance. A little girl was saying that her grandmother was carried with a wheelbarrow when she was going into a coma, and remembered certain sequences when the wheelbarrow jumped from time to time, and she would a little bit come out of the coma... Instead of an ambulance, she was carried with the countryside wheelbarrow (FG3). 


\section{National Health Program}

In the case of National Programs for eradication or control of a disease, the National Diabetes Program in Romania in this case, it is important to calibrate the allocated financial resources in order to provide quality care. The financial and material resources invested in health programs vary from state to state, depending on the philosophy behind public policies, but also on the cost-benefit ratio.

I find it very difficult not to bave the exchange needles, although they are disposable and the diabetic patient gets infected very quickly. Much faster than a normal person (FG2).

The state of the chronic patient deteriorates over time, which determines at one point the need for a companion and integration into a certain degree of disability.

With many years of diabetes, all possible complications have occurred so that I no longer feel hypoglycaemia due to neuropathy. I do not sweat anymore, I do not feel anything at all, I go straight into a coma and then I should have a companion (FG2).

Persons suffering from chronic disabling illnesses are considered entitled to receive state support, including disability pension, attendant, free access to treatment, etc. When the lack of these resources jeopardizes the state of health and even the patients' lives, public health policies will always be ethically criticized, in the sense of not solving the inequities regarding access to health services and the failure to promote the right to life of patients. Obviously, no public health insurance system can necessarily solve all the inequities that have arisen, which is why it is necessary to have private health insurance. However, a number of redistributive policies based on the principle of subsidiarity in the provision of healthcare resources would be needed precisely to compensate for the structural failure in such cases of long-term chronic disabling illnesses that do not allow the patient to be insured in the contributory system.

I do not have it because he does not want to give me the right to have an attendant, money with which I would buy tests that are for the companion. My little girl is helping me. Since I gave birth, I have this problem so badly, after I gave birth, I had a bad luck that I could not take the money for two years, and then all of my savings went on blood glucose tests. Now I have no money but a 2-million and something disability pension that I cannot survive with, neither eat nor take tests. (FG2).
Equity in Health Policies

Another element of social inequity highlighted is the refusal of the public health insurance system to settle a number of treatments, especially when they are emergency treatments applied to chronic patients who have a certain degree of disability that prevents them from be ensured in contributory insurance systems. In these cases, the moral failure should be compensated by the state, which has public responsibility for the public's welfare, where they cannot secure a life within the acceptable limits of well-being at the level of that society.

I was in Vienna, I was sick, I was in a coma there, the person who was with me called the ambulance and came home with a 550-euro settlement. I went to the Insurance Houses today in Audience and they told me that I had to pay because the Romanian State would not settle the costs (...) I have insurance. Both as a disabled person and with the pension house. They do not want to settle (FG4).

When the chronic patient's incapacity for work occurs, this is reflected on the other members of the family, especially children who are forced to suffer a series of deprivations, and the result of social inactivity (Lăcătuşu, 2018), where it is missing or is dysfunctional to a non-contributory social security system based on the principle of subsidiarity.

My little girl nonetheless, and I said I would give her for adoption, I was really desperate that I would not be able to feed her, really desperate that having diabetes, I should eat and thus be healthy so that I can raise her. Last year someone taught me to retire on sickness with my old age, and I would still get 3 million, but I still cannot get my tests and eat normally. As long as I have a baby and he has to eat too, he does not have a father, so it's only me. I mean, she is very much needed to help me when I'm in a coma and call the ambulance (FG2).

The chronic patient's needs significantly affect family members, especially when the patient is a parent, family provider. Close relatives will radically change their lifestyle to help the patient, going to personal sacrifices and renunciations that involve not only personal comfort, but also some aspects essential to their own development, such as school in the present case.

There are days when she does not go to school because she has to stay with me, because I am sick and afraid of going into a coma and she would return to find me dead at home, so she stays at home too (FG2). 
Non-discrimination and equal treatment in health care policies

Discrimination in the employment, even if the person has all the necessary skills, and the state of health allows him to work, if he takes certain precautionary measures or if he is offered a number of particular labour conditions, can be an additional source of stress, that adds to the inconveniences caused by the illness, with negative consequences for the social integration of the chronic patient.

I tried to get hired in 2-3 companies and told them I needed a break that I could not announce in advance because I did not know the exact time. They told me that they would see, and at the end they said no (FG2).

Blood glucose control in the case of diabetic patients, based on glucose tests and the glucose meter, is a key to effective self-care management. In the absence of these, patients estimate the need for insulin after symptoms, but the tests allow dose calibration. As such, patients' access to these tests is a prerequisite for running a National Diabetes Program effective to keep disease progression under control, and avoid complications in patients. If the patient does not receive such tests, the state should be made responsible for the worsening of his or her state of health and the failure to ensure the right to life and the right to health of patients.

As long as I have tests I go on good glycaemic, when I don't - I lose control, because at night, of fear not to make bypoglycaemia over night, I eat a little more. And in the afternoon until the evening, I feel bad, bad, I have a state of depression because I had problems with these too. In the evening when I get home I feel good again (FG 6)

Chronic patients may suffer from different forms of discrimination, including employment, integration into social life, school, etc. Discrimination may be the result of a misunderstanding of the specificity of the disease, its way of transmission, or a lack of accountability for potentially hazardous situations such as accidents at work, or even conditions of illness, coma, etc. that may occur during the course of the activity.

(..) I sent the papers (for a job) and then I don't know how I told her I had diabetes and I had to go. There were a few more days. She then stopped calling me suddenly, and then I felt very bad, for a long time. (FG 5).

The importance of access to technology from the perspective of equity of the health system.

Access to communication and documentation technologies is an essential step in obtaining the real expressive autonomy of the patient by empowering them with their own health management and self-care. On the other hand, sources of information should be carefully chosen so as not to pose health risks by applying inconsistent, miraculous therapeutic solutions that can lead to a deterioration of the patient's health. The patient's communication with other patients, online support groups, online patient communities, play an important role in maintaining appropriate tone and mutual motivation of patients to increase their therapeutic adherence, and to create true therapeutic alliances between physicians and patients.

I have seen, I've even got informed over the internet, I use the internet very often and I'm often interested in everything from abroad, it's much better about everything, especially in diabetes. I even talked to a diabetic from abroad, I do not know where from exactly, a while ago, and she told me it's like she would not have diabetes (FG 5)

Another important role of current technology is to create products that enable patients to adopt a lifestyle as normal as possible, and thus to express maximum expressive autonomy. Food technologies bring a number of lifestyle-specific products to different categories of patients, such as sugar-free sweets, and with rapid absorption in diabetic patients.

I do not really like that, for example, I drink juice and everything that is light or sugar-free, there is Pepsi, and as you know, it has caffeine, and that does not suit me too. It's a special sweet that's called, I do not know what its called. A type of glucose that absorbs very quickly, special for diabetics $(F G 5)$.

\section{CONCLUSIONS}

The appropriate health programs for chronic patients should take into account the extent of their autonomy, not only in the decisional autonomy but also in the expressive, in other words, the patients' ability to achieve an efficient management of self-care.

\section{A C KN OWLED G MEN T}

Data collection was conducted in the framework of the research entitled "Stil de viata si comportament in sanatate la pacientii cronici" [Lifestyle and Health Behaviour in Chronic Patients], run at the "Gr. T. Popa" University of Medicine and Pharmacy of Iasi, Romania. The article is a secondary data analysis.

\section{REFRENCES}

Britt, T. W., Moore, M. A., Adler, A. B., Bartone, P. T. (1995). Responsibility, stress and health: Testing the triangle model of responsibility. Paper presented 
at the Annual meeting of the American Psychological Society, New York, USA. doi:10.21236/ada298900

Capplen, A., \& Norheim, O. F. (2005). Responsibility in health care. A liberal egalitarian approach. Journal of Medical Ethics, 31(8), 476-480. doi:10.1136/ jme.2004.010421

\section{Casa Națională de Asigurări de Sănătate} (CNẢS). (2018). Ordinul nr. 1332/2018 privind modificarea Ordinului președintelui Casei Naționale de Asigurări de Sănătate nr. 299/2017 pentru aprobarea machetelor de raportare fără regim special a indicatorilor specifici și a Metodologiei transmiterii rapoartelor aferente programelor/subprogramelor naționale de sănătate curative [Order no. 1332/2018 amending the Order of the President of the National Health Insurance House no. 299/2017 for the approval of non-specific reporting models of specific indicators and of the Methodology for the transmission of reports related to national curative health programs / subprograms]. Monitorul Oficial al României, 834, 2018, October 01.

\section{Casa Națională de Asigurări de Sănătate}

(CNÁS). (N.D.). Programul național de diabet zaharat [National Diabetes Program]. Retrieved from http:// www.cnas.ro/cjasvs/media/pageFiles/PROGRAMUL\%20NA\%C5\%A2IONAL\%20DE\%20DIABET\%20ZAHARAT.pdf

Council of the European Union (CEU). (2011). Conclusions on "Innovative approaches for chronic diseases in public health and healthcare systems" of 7 December 2010. Official Journal of the European Union, 2011/ C74/03.

Epping-Jordan, J. E., Pruitt, S. D., Bengoa, R, WAGNER, E. H. (2004). Improving the quality of health care for chronic conditions. Quality and Saftey in Health Care, 13(4), 299-305. doi:10.1136/ qshc.2004.010744

Everson, S. A., Maty, S. C., Lynch, J. W., Kaplan, G. A. (2002). Epidemiologic evidence for the relation between socioeconomic status and depression, obesity, and diabetes. Journal of Psychosomatic Research, 53(4), 891-895. doi:10.1016/s0022-3999(02)00303-3

Federation of European Nurses in Diabetes (FENDT) \& International Diabetes Federation Europe (IDF Europe). (2008). Diabetes. The policy puzzle: Is Europe making progress? Retrieved from https://www.fend. $\mathrm{org} /$ sites/fend.org/files/EU_diabetes_policy_audit_2008.pdf

GALAN, D. (2017). Importance of psycho-physical training over the seasons of life. Logos Universality Mentality Education Novelty, Section: Social Sciences, VI(1), 51-60. doi:10.18662/lumenss.2017.0601.05

KAMBERI, F. (2018). Knowledge and attitudes of nurses toward the use of nursing diagnosis in clinical practice. Eastern European Journal of Medical Humanities and Bioethics, 2(2), 43-55. doi:10.18662/eejmhb/14

LĂCĂTUşu, R. (2018). Sociologie medicală. Universitatea de medicină și farmacie Carol Davila, Bucharest, Romania. Retrieved from https://
www.academia.edu/21947134/SOCIOLOGIE MEDICAL\%C4\%82_-curs_op\%C5\%A3ional_Anul_II_Medicina_General\%C $4 \% 83$

Manolachi, V., \& Vizitei, N. (2018). Psychology of sport: The need for modernization and the ways of its implementation. Revista Romaneasca pentru Educatie Multidimensionala, 10(2), 58-68. doi:10.18662/ $\mathrm{rrem} / 46$

Moisa, S., PÂrvu, A., \& IoAn, B. (2019). Palliative care in Romania and Lithuania - Between the necessity of terminal patient assistance and the rigors of resource allocation. Postmodern Openings, 10(1), 53-67. doi: $10.18662 / \mathrm{po} / 55$

Singh, D., \& HaM, C. (2006). Improving care for people with long-term conditions: A review of UK and international frameworks. Research report, University of Birmingham. Retrieved from http://www.improvingchroniccare.org/downloads/review_of_international_frameworks_chris_hamm.pdf 